sequencing will nonetheless require some changes to the HGP's original agreement, says Mark Guyer, assistant director for scientific coordination at the National Institutes of Health's National Human Genome Research Institute, which is managing the US end of the publicly funded mouse project.

Strict adherence to earlier agreements would have meant that the mouse data were not publicly available until the organism was sequenced three times over and then assembled - a milestone targeted for April. Setting up a database of mouse sequence fragments may be an interim solution. "If we had kept to our earlier policy, the data would not ave been released for six months," says Guyer.

P.S.

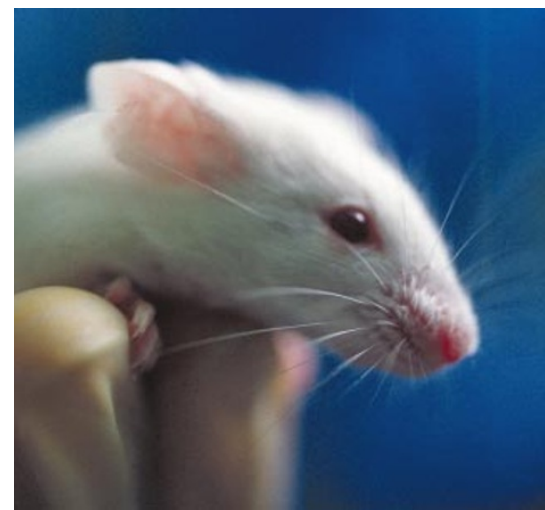

Shotgun success: the mouse genome has already been sequenced once over.

\title{
Publication deal for Celera sparks row over data access
}

Science magazine has released details of the terms under which it plans to publish Celera Genomics' paper on the human genome - and drawn sharp criticism over the limits that the terms set on data access.

Celera and Science have agreed that publicly funded scientists can download up to one megabase of data without signing a material transfer agreement. But privately funded users must sign such an agreement stating that they will not commercialize their results or redistribute the data.

The arrangement has potentially profound significance, some researchers say, because it could set a precedent for scientists to publish papers without unencumbered access to supporting data.

"What will happen if someone else from the academic sector says, 'I have an interesting result to report, but I can't give you all the data'?" asks Harold Varmus, president of the Memorial Sloan-Kettering Cancer Center and former National Institutes of Health director. Varmus was one of several scientists who advised Science on the terms. But the advisers are not all in agreement with the announced policy, he says.

When the agreement was announced, Bruce Alberts, president of the National Academy of Sciences, issued a brief statement of support, saying that it may serve as a

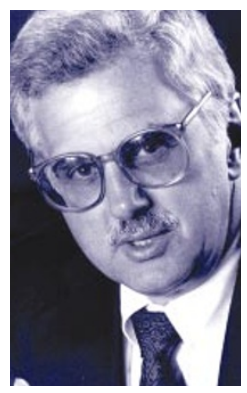

Bruce Alberts: deal won't work for private sector. way to prompt more companies to make their genomic data available.

But this week, Alberts - who says that the statement reflected his own views, not those of the academy backed off from this. In an interview, he said that the deal could work for publicly funded scientists, but that the terms for private ones appear unworkable. "The data

should be available both to the public sector and private," he says.

The agreement has drawn vocal criticism from some researchers. Ewan Birney, team leader of genomic annotation with the European Bioinformatics Institute in the UK, co-authored an open letter to bioinformaticians attacking the arrangement. He says it is problematic for computational biologists, because they work with large data sets, whose transfer is restricted by the agreement. "This deal is bad for bioinformatics, but palatable for single gene biology," Birney says.

| http://www.sciencemag.org/feature/data/ announcement/genomesequenceplan.shl

\section{Japan pins hopes on fast-breeder nuclear option}

David Cyranoski, Tokyo.

Bucking the international trend towards ending programmes to build nuclear power plants that breed their own fuel, Japan is drawing up plans to reopen its prototype fast-breeder reactor.

The Monju reactor at Fukui, 500 kilometres southwest of Tokyo, has been closed since an accident in 1995, when sodium coolant leaked from a cracked pipe and burst into flames. There were no injuries, but local residents were angered by an attempt to cover up the incident.

Fast-breeder reactors can potentially use uranium fuel many times more efficiently than conventional reactors. But they are expensive to build, and only cover their costs if uranium is expensive, which it has not been. The United States, Britain, France and Germany have all halted their fast-breeder programmes in recent years.

The Monju reactor's reopening is part of a long-term plan released by the Japan Atomic Energy Commission last month.
Japanese officials argue that, because of its lack of fossil fuels and other natural resources, the country has no choice but to develop nuclear energy.

The Japan Nuclear Cycle Development Institute (JNC), which operates Monju, must gain approval from the local governor before it can prepare for the reopening. Officials say operations will resume in 2003 at the earliest and run for 20 years.

Their goal is to show that fast-breeder reactors can operate continuously and reliably, and to establish safe and effective techniques for handling sodium. The JNC says it plans to turn Monju into "an international centre for cooperation, open to researchers from Japan and abroad".

But not everyone is convinced that the JNC is adequately concerned about safety at the reactor. Critics complain about the absence of a properly independent safety commission, akin to the US Nuclear

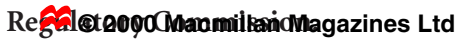
The central government is also
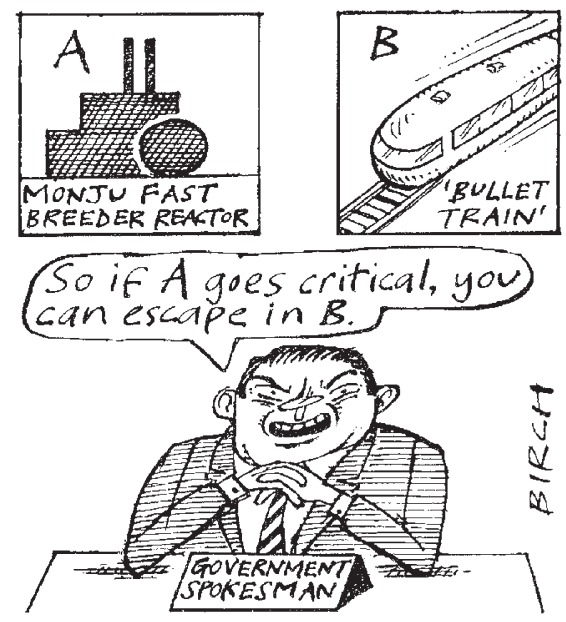

negotiating the possibility of passing a bullet train through Fukui, where Monju is located, arousing suspicions that the government is trying to buy off local criticism. http://sta-atm.jst.go.jp/jicst/NC/tyoki/siryo/ tyoki_e1208/siryoe.htm 